\title{
Abdomen agudo secundario a perforación duodenal por ingesta de cepillo de dientes*
}

\author{
Drs. MARIO FERRARIO B. ${ }^{1}$, ERWIN BUCKEL G. ${ }^{1}$, ÁLVARO ROJAS L..${ }^{1}$, ÁlVARO CÁMBARA P. ${ }^{1}$ \\ 1 Unidad de Trasplantes Clínica Las Condes, Santiago, Chile.
}

\section{Acute abdomen secondary to duodenal perforation caused by toothbrush intake}

Mujer de 38 años de edad se presenta en servicio de urgencia por dolor abdominal intenso. Al examen físico destaca Blumberg difuso y abdomen en tabla, sin compromiso hemodinámico.

TC de Abdomen informa imagen compatible con cuerpo extraño de $19 \mathrm{~cm}$ de longitud, en lumen duodenal, perforando la pared de la tercera porción, quedando su extremo distal en situación retroperitoneal, peri renal (Figuras 1A y 1B). A pesar de reinterrogarla la paciente niega su ingestión.
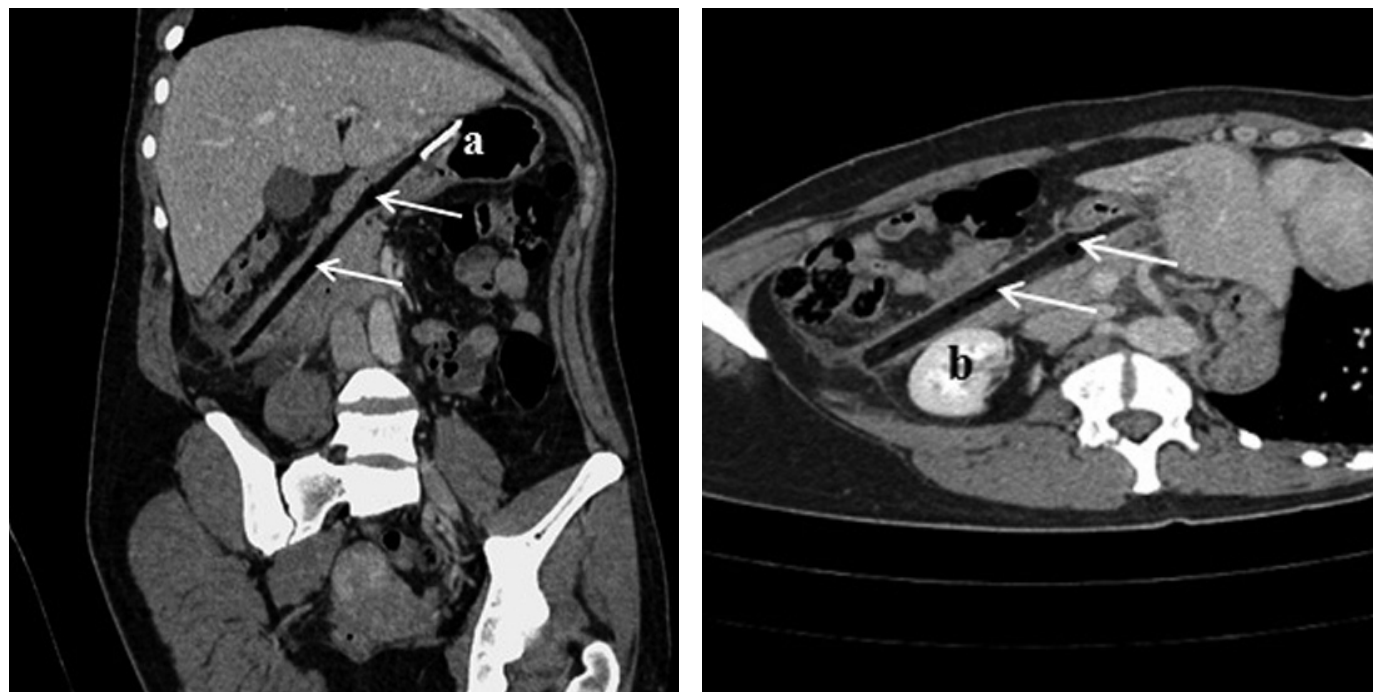

Figura 1A y 1B. TAC de Abdomen mostrando el cuerpo extraño (flechas) que se extiende desde el píloro (a) hasta llegar a la inmediación del riñón derecho (b).

*Recibido el 28 de junio de 2012 y aceptado para publicación el 25 de julio de 2012.

Los autores no refieren conflictos de interés.

Correspondencia: Dr. Álvaro Cámbara P.

Lo Fontecilla 441, Las Condes.

acambara@clc.cl 
En cirugía de urgencia se retira cepillo de dientes mediante gastrotomía, rrafia duodenal con monocryl, cierre pilórico con vicryl 0 . Se realiza gastroyeyunoanastomosis en Y de Roux y coledocostomía con sonda $\mathrm{T}$.

La ingesta de cuerpos extraños se produce típicamente en población pediátrica o adultos con patología psiquiátrica, abuso de sustancias o demencia ${ }^{1}$.

Alrededor del $80 \%$ de los cuerpos extraños que se ingieren pasan por el tracto digestivo sin complicaciones. La probabilidad de que un cuerpo extraño se complique es más alta para objetos alargados, particularmente cuando miden más de $6 \mathrm{~cm}$ siendo una indicación de tratamiento endoscópico de urgencia ${ }^{2}$.
Cuando exista una alta sospecha de perforación o imágenes compatibles se debiese proceder a una resolución quirúrgica, como en el presente caso.

\section{Referencias}

1. Velitchkov NG, Grigorov GI, Losanoff JE, Kjossev $\mathrm{KT}$. Ingested foreign bodies of the gastrointestinal tract: retrospective analysis of 542 cases. World J Surg. 1996;20:1001-5.

2. ASGE Standards of Practice Committee, Management of ingested foreign bodies and food impactions. Gastrointest Endosc. 2011;73:1085-91. 